日臨外会誌 $62(1), 1-7,2001$

原

術前，術後の介護評価からみた 80 歳以上高齢者

消化器外科手術症例の検討

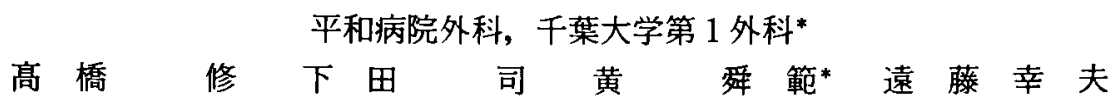

1992年 4 月より 1999年 3 月までの80歳以上高齢者消化器外科手術40例につき術前, 術 後の日常生活活動（以下，ADL)，日常生活自立度 (以下，寝たきり度）の変化を中心に 検討した. 術前検查值異常, 併存疾患は $90 \%$ で認められたが緊急手術例や悪性腫瘍に対 する姑息手術症例を除く待機手術症例では重篤な合併症も少なく耐術可能であった。し かし退院可能となった30例において術前後の ADL変化をみると, 移動, 排泄面を中心 に，6例 $\left(20^{\circ}{ }_{0}\right)$ で何らかの低下を認め，㨧たきり度においては「生活自立」から「骎 たきり」へと著明に上昇した症例も2 例認められた。高齢者手術に扔いては手術侵襲の 軽減を図ることはもちろんであるが, 而術のみにとらわれず, 術後の ADL の低下を考慮 し，適切な介護支援が提供できるような体制を整えて手術に臨むべきであると思われた。

索引用語：高齢者手術，ADL，介護評価

はしめに

近年, 平均寿命の延長や, 手術手技, 㑣酔法, 術前 術後管理の進歩に伴い, 高齢者に对する手術適応は拡 大されつつある.当院においても高齢者手術は年々增 加しているか，これにつれ，耐術し，予定手術を施行 しえたにもかかわらず，術後に日常生活活動（以下 ADL)が低下することにより入院期間が延長したり， 寝たきり度が上昇することにより，本人への負担ばか りでなく，家族の介護負担が增大する症例がみられる ようになってきた。高齢者手術に関し，その適応，手 術法, 術前危険因子, 合併症, 予後などに関する報告 は数多くみられているが(1-1)，これら術後に抗こる ADLの低下や寝たり度の上昇に関する報告はあま

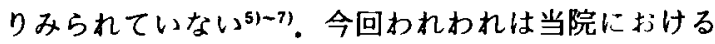
80歳以上高齡者の ADL, 寝たきり度の変化を中心に検 討したので報告する.

\section{対象と方法}

1992年 4 月より1999年 3 月までの 7 年間において, 当院で施行された 80 歳以上高齢者外科手術は 55 例. こ のうち消化器外科手術症例は, 男性17例, 女性23例の

2000 年 4 月 26 日受付 2000 年10月23日採用

〈所属施設住所〉

干230-0017 横浜市鶴見区東寺尾中台28- 1
計40例，平均年齢は84.4歳であった(表 1 )。これら40 例に扔いて, 疾患, 術前検查值異常, 併存疾患の有無, 手術術式, 術後合併症につき，また40例のうち術後重 篤な合併症を抗こして死亡した 6 例と，悪性疾患に対 する姑息手術後，原疾患の悪化により退院できないま ま死亡した山例を除き，退院可能であった30例につい ては術前術後の ADL および誛たきり度の変化を検討 した，ADLの状況は，介護保険制度において要介護度 の判定に利用される基本調查項目のなかの「障害老人 の日常生活自立度 (寝たきり度)」の判定基準 ${ }^{8} に よ り ，$ 移動, 排泄, 食事, 入汾, 着替, 整容, 意思柾通の 7 項目につき, いわす「自立」,「部分介助」,「全面介 助」の 3 段階評価し(表 2 ), 寝たきり度は「生活自立」, 「準寝たきり」,「寝たきり」の3 段階で判定した（表 3 ).

表 1 当院における高秢者（80歳以上）外科手術 症例

\begin{tabular}{|c|c|c|}
\hline & 全外科手術 & 消化器外科手術 \\
\hline 男 性 & 26例 $(84.6)$ & 17例 (N4.6) \\
\hline 女 性 & 29例 $(84.3)$ & 23 例 $(x+3)$ \\
\hline 計 & 55例 $(84.5)$ & 40 例 $(84 . \overline{4})$ \\
\hline
\end{tabular}

(平成 4 年 4 月 古成11年 3 月) 
表 2 ADL の状況

\begin{tabular}{|c|c|}
\hline 動 & $\begin{aligned} \mathrm{a}: \text { : 時間がかかっても介助なし } \\
\text { に一人で歩く } \\
\mathrm{b} \text { : : 手をかしてもらうなし、一 } \\
\text { 部介助を要する } \\
\mathrm{c} \text { ：全面的に介助を要する }\end{aligned}$ \\
\hline 食事 & 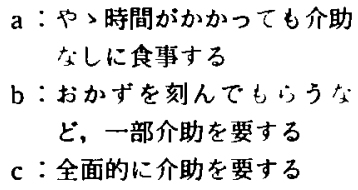 \\
\hline 排 & 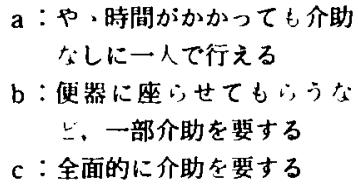 \\
\hline 入 浴 & 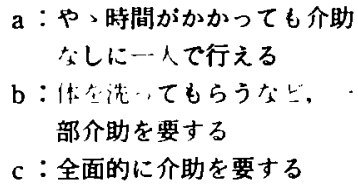 \\
\hline
\end{tabular}

\section{表 3 日常生活自立度（寝たきり度）}

\begin{tabular}{|c|c|}
\hline 生活自立 & $\begin{array}{l}\text { 何らかの障害等を有すうお，日常生活はほほ自 } \\
\text { 立しており䖵力で外出する } \\
\text { 1. 交通機関等を利用して外出する } \\
\text { 2. 腾近所へなら外出する }\end{array}$ \\
\hline 华椄たきり & 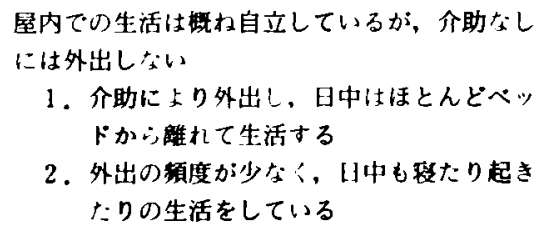 \\
\hline \multirow{2}{*}{ 糞たきり } & 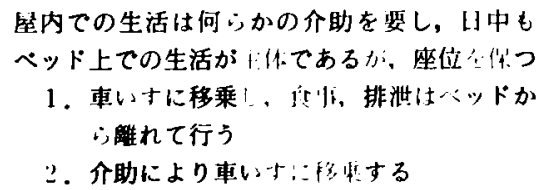 \\
\hline & 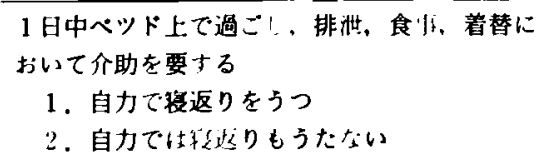 \\
\hline
\end{tabular}

\section{結 果}

術後，退院可能であった30例中 ADL の低下は男性 4 例，女性2例の計 6 例 $(20 \%)$ で認められた。

\section{1. 疾患}

对象40例中，要性疾患は25例，良性疾患は15例であ

\begin{tabular}{|c|c|}
\hline 着 替 & $\begin{aligned} & \mathrm{a}: \text { : } \text { な時間がかかっても介助 } \\
& \text { なしに一人で行える } \\
& \mathrm{b}: \text { : そでを通してもらうなど一 } \text { 部介助を要する } \\
& \mathrm{c} \text { ：全面的に介助を要する }\end{aligned}$ \\
\hline $\begin{array}{c}\text { 整 容 } \\
\text { (身たしなみ) }\end{array}$ & 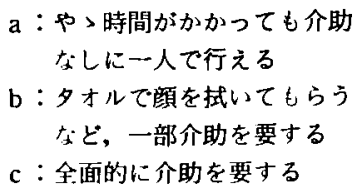 \\
\hline $\begin{array}{ll}\text { 意 } & \text { 思 } \\
\text { 柾 } & \text { 通 }\end{array}$ & 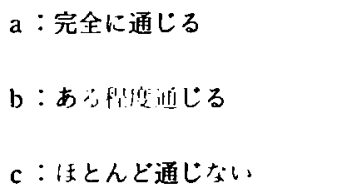 \\
\hline
\end{tabular}

表 4 手術対缘疾患

\begin{tabular}{|c|c|c|c|c|}
\hline & 恶 性 疾 & 患 & 良 性 疾 & 患 \\
\hline 17 & 癌 & 6 & 胆 石 症 & $9(2)$ \\
\hline 結 & 脂 雷 & 7 & 急性虫垂炎 & $3(2)$ \\
\hline 直 & 腸 薄 & $6(1)$ & 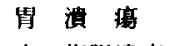 & 1 \\
\hline 小 & 晹 癌 & 2 & 十二指脘嘳場 & 1 \\
\hline 食 & 道 癌 & $1(1)$ & 腸＼cjkstart閉 塞 & 1 \\
\hline 脺 & 頭 部 腐 & 1 & & \\
\hline ₹ & の 他 & 2 & & \\
\hline \multicolumn{2}{|r|}{ 計 } & 25 & & 15 \\
\hline
\end{tabular}

り，悪性疾患では結腸癌，直腸癌など，下部消化管に やや多い傾向がみられた。 また良性疾患では胆石症が 最も多かった.このうち ADL 低下症例は小腸癌 1 例， 食道癌 1 例, 胆石症口例, 急性虫垂炎 2 例であり，良 性疾患の手術においても術後 ADLの低下が認められ た(表 4 ).

\section{2. 術前検查値異常, 併存疾患}

術前娭植估異常，併存疾㭧の有無法，心，肺，肝，

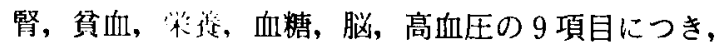
表 5 の基準で検討したが，36例（901\%）で何らかの異 常が認められ，高血圧 57.5 ”。，心疾㭧 $37.5 \%$ と循環器 系の異常が多く認められた。術後 ADLが低下した 6 
表 5 術前検査値異常, 併存疾患の基準

\begin{tabular}{|c|c|}
\hline 心 & ECG異常または虚血性心疾患，不整脈で治療中 \\
\hline 帽 & ${ }_{\mathrm{o}} \mathrm{VC}<<10^{\circ} \mathrm{O}_{\mathrm{O}} \quad 1$ 秒率 $<70 \% \quad \mathrm{PaO}_{2}<70 \mathrm{mmHg}$ \\
\hline 肝 & GOT, GPT $>60 \mathrm{IU} / 1 \quad$ T.Chol $<120 \mathrm{mg} / \mathrm{dl}$ \\
\hline 肾 & PSP120分値 $<50^{\circ} \%$ Cre $1.6 \mathrm{mg} / \mathrm{dl}$ \\
\hline 費血 & $\mathrm{Hb}<10.0 \mathrm{~g} / \mathrm{dl}$ \\
\hline 栄養 & T.P. $<6.0 \mathrm{~g} / \mathrm{dl} \quad \mathrm{Alb}<3.0 \mathrm{~g}{ }^{\prime} \mathrm{dl}$ \\
\hline 血咗 & FBS $>130 \mathrm{mg} / \mathrm{dl}$ 樯尿病で治淿中 \\
\hline 缕 & 檤血管疾患の既往 (+) \\
\hline 高血压 & $\begin{array}{l}\text { 収縮期庄 }>160 \mathrm{mmHg} \text { 㹡張期区E }>95 \mathrm{mmHg} \\
\text { 高血压で治療中 }\end{array}$ \\
\hline
\end{tabular}

表 6 術前検査值異常, 併存疾患

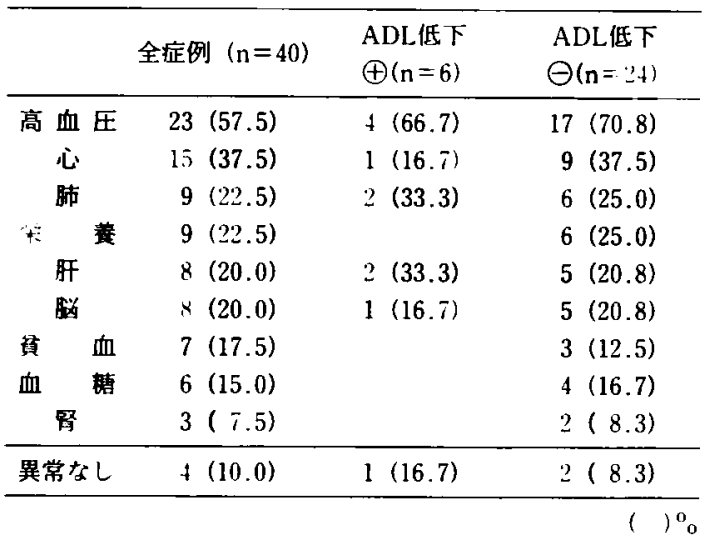

例においても5例に徒前検査值異常を認めたが, ADL の低下が認められなかった症例が平均2.4項目の異常 であったのに対し，ADL 低下例は1.7項目と，むしろ 術前検查值異常は少ない傾向去していた（表 6 ).

\section{3. 手術術式}

良性疾患15例中 5 例は緊急手術であった。このうち 胃, 十二指腸謴瘍症例は，いずれも吐血し，内視鏡的 止血を試みたものの止血出来ず，開腹となった。また 開腹胆摘症例は，腹腔鏡下手術導入以前の症例であっ た。術後に ADLの低下を認めたのは胆摘, 総胆管切 開, ドレナージ症例で 2 例, 虫垂切除術, 回盲部切除 術で各 1 例であった(表 7 )。悪性疾患25例中17例は切 除可能であったか;，残りのメ例は入院時すで病状の 進行が著明であったり，穿孔による緊急手術となり全 身状態も焏めて不良のため姑息手術となった，術後の ADL 低下は非開胸食道抜去術と小腸切除術で認めら れた (表 8). 胃癌, 大腸癌の術後には ADL の低下が みられなかったのに対し，虫垂切除術のように，比較 的侵㜔の少ないと思われる手術においても術後の ADL 低下が認められていた。
表 7 手術術式(良性疾患)

\begin{tabular}{|c|c|c|}
\hline 疾 患 & 手術術式 & \\
\hline \multirow{3}{*}{ 胆 石 症 } & 開腹胆摘術 & 3 \\
\hline & 腹胫鏡下胆摘術 & 1 \\
\hline & 胆摘・総胆管切開・ドレナージ & $5(2)$ \\
\hline \multirow{2}{*}{ 急性虫垂炎 } & 虫垂切除術 & $2(1)$ \\
\hline & 回盲部切除術 & $1(1)$ \\
\hline 胃・十二指腸溃痬 & 胃切除術 & 2 \\
\hline \multirow{2}{*}{ 腸閉塞 } & 椺保制離術 & 1 \\
\hline & & $15(4)$ \\
\hline
\end{tabular}

表 8 手術術式（悪性疾患）

\begin{tabular}{|c|c|c|c|c|}
\hline \multirow{2}{*}{$\begin{array}{ll}\text { 疾 } & \text { 患 } \\
\text { 胃 } & \text { 癌 }\end{array}$} & \multicolumn{2}{|l|}{ 切除手術 } & \multicolumn{2}{|l|}{ 姑息手術 } \\
\hline & 胃切除術 & 5 & 胃空腸吻合術 & 1 \\
\hline \multirow{5}{*}{ 大腸䄸 } & S状結腸切除術 & 4 & 人工肛門造設術 & 2 \\
\hline & 結腸右半切除術 & 1 & 穿孔閒鎍・ドレナーシ & 1 \\
\hline & 腰会陰式直腸切断術 & 2 & & \\
\hline & 低位前方切除術 & 2 & & \\
\hline & ハルトマン手術 & 1 & & \\
\hline 小腸瘦 & 小腸切除術 & $1(1)$ & 晹吻合術 & 1 \\
\hline 食道密 & \multicolumn{2}{|c|}{ 非開胸食道抜去衍 1 (1) } & & \\
\hline 膵頭部痹 & & & 胆管空腸吻合術 & 1 \\
\hline \multirow{2}{*}{ その他 } & & & 腸吻合術 & 1 \\
\hline & & & トレ+ージ & 1 \\
\hline 計 & & $17(2)$ & & $\dot{s}$ \\
\hline
\end{tabular}

\section{4. 術後合併症}

術後合併症は15例（37.5\%）で認められた。緊急手 術 8 例中, 急性虫垂炎症例を除く5例はいずれも重篤 な合併症をおこし在院死亡となった。しかし待機手術 例においては縫合不全から腹膜炎を併発した 1 例を除 き、いずれも合併症は軽度であり，保存的治療により 軽快した(表 9)。街後合併症をおこしたものの，軽快 し退院可能であった 9 例中， 3 例（33\%）において術 後 ADLの低下が認められたのに対し, 合併症をおこ さずに退院した21例においては ADLの低下は 3 例 (14\%)であり, 術後合併症を併発した症例は，おこ さなかった症例に比し, ADL の低下をおこしやすい傾 向を示していた。

\section{5. 術前術後の ADL 变化}

術後 ADL の低下が認められた 6 例に打いて，その 低下の内容を検討したところ,移動においては術前「自 
表 9 術後合併症症例

\begin{tabular}{|c|c|c|c|c|c|c|}
\hline & \multicolumn{2}{|c|}{ 年龄 性別 } & 病 名 & \multirow[t]{2}{*}{ 術 式 } & \multirow[t]{2}{*}{ 合 併 症 } & \multirow{2}{*}{$\frac{\text { 転 㷌 }}{\text { 術後9日 死亡 }}$} \\
\hline (1) & 83 & $\mathrm{~F}$ & 十二指陽淟瘍 & & & \\
\hline (2) & 84 & M & 胃謴瘍 & 胃切除術* & 肺炎・繾合不全 & 術後66日 死亡 \\
\hline (3) & 94 & $\mathrm{~F}$ & S状結腸筁 & 穿孔閉鎖・ドレナージ* & 腎不全 & 術後 8 日 死亡 \\
\hline (1) & 85 & $\mathbf{F}$ & 下腹腫維 & ドレナージ & 肝·腎不全 & 術後68日 死亡 \\
\hline (5) & 83 & $\mathrm{~F}$ & 直晹䌿 & 人工肛門造設術* & $\mathrm{DIC}$ & 術後63日 死亡 \\
\hline (6) & 82 & $\mathrm{~F}$ & 胃 我 & 胃切除術 & 䋖合不全・腹膜炎 & 術後68日 死亡 \\
\hline (7) & $80^{* *}$ & $M I$ & 急性虫垂炎 & 虫垂切除術 & 肺炎・皮下㧁痬 & 軽快退院 \\
\hline (8) & $86^{\circ}$ & M & 急性虫垂炎 & 回盲部切除術 & 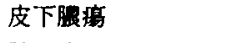 & 軽快退院 \\
\hline (9) & 92 & $\mathrm{M}$ & 胃 虎 & 胃切除術 & 肺 炎 & 軽快退院 \\
\hline (11) & $8: 3$ & $\mathbf{F}$ & 胃 舟 & 胃切除術 & 肺＼cjkstart炎 & 軽快退院 \\
\hline (11) & $80^{\circ \bullet}$ & $\mathbf{F}$ & 食道㵧 & 非開胸食道抜去術 & 気胸・呼吸機能低下 & 軽快退院 \\
\hline (12) & 89 & M & 結胆病 & 結腸右半切除術 & 肝機能障害 & 軽快退院 \\
\hline (13) & 83 & MI & 結腸癌 & S状結腸切除術 & 皮下膿瑒 & 軽快退院 \\
\hline (14) & 85 & $\mathrm{M}$ & 直腸㾇 & ハルトマン手術 & 皮下脿㜛 & 軽快退院 \\
\hline (15) & 80 & $\mathrm{~F}$ & 直腸我 & 低位前方切除術 & 䋖合不全 & 軽快退院 \\
\hline
\end{tabular}

**ADL低下症例 *緊急手術
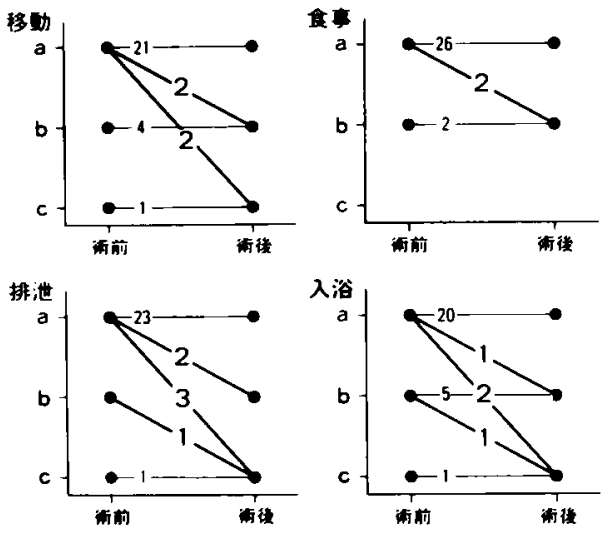

図 1 術前, 術後の ADL 变化 (1)
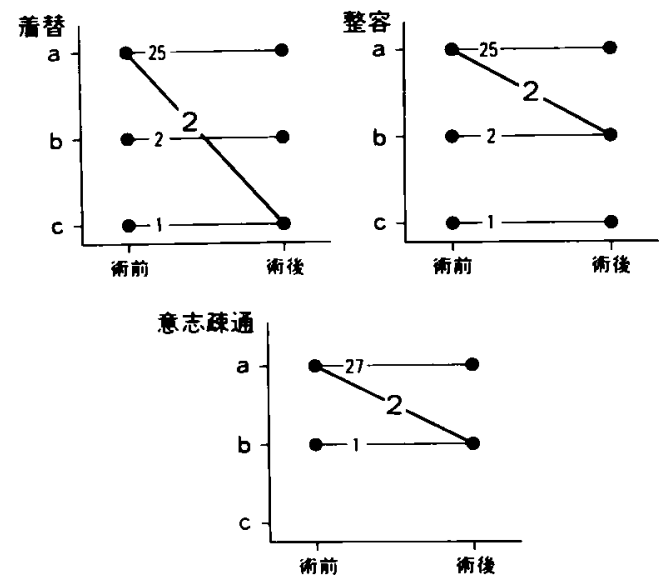

図 2 術前, 術後の ADL 变化 (2)
立」であった25例中 2 例が「部分介助」に，2 例が「全 面介助」にまで低下し，排泄では 2 例か门自立」から 「部分介助」に，3 例か「全面介助」に。また 1 例は 「部分介助」から「全面介助」へと低下した，入浴て は「自立」から「部分介助」1例,「自立」から「全面 介助」 2 例. また「部分介助」から「全面介助」が 1 例認められた。食事, 整容, 意思柾通においては各 2 例が「自立」から「部分介助」へと低下し，着替えて は 2 例で「自立」から「全面介助」への低下がみられ た(図 1,2).

\section{6. 術前, 術後の赛たきり度の变化}

術前評価は「生活自立」26例，「準ねたきり」2 例, 「骎たきり」2例であったが，術後「生活自立」から
「準浸たきり」になったものが 1 例，「準唚たきり」か ら「寝たきり」になったものが1例みられたほか，術 前「生活自立」でったにもかかわらず，「寝たきり」 になったものが2 例認められていた（図 3 ).

\section{考 察}

近年, 平均寿命の延長や, 手術, 麻酔手技, 周術期 管理の進歩により，高齢者手術は増加傾向にあり，そ の適応，risk factor，合併症，手術法などに関してさ まざまな報告がなされているりー゙。一般に高齢者ては 加齢により, 循飄器, 呼吸器など各種臓器の機能が低 下し，種々の基礎疾患在併存しているといわれてお り ${ }^{3 \cdot 93}$, 高齢者手術における術前臓器障害および検査值 


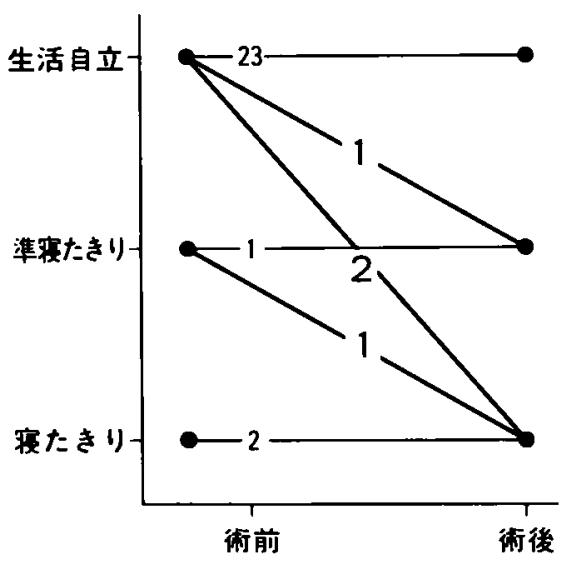

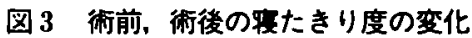

異常の診断基準も各種検討されているが(0)-12)，今回著 者らが桜本ら 栄養, 血糖，膇の 8 項目に高血圧を加えた 9 項目で検 討したところ, $90 \%$ の症例で何らかの異常か認められ， 諸家の報告と同様, 循環器系の異常が多くみられてい た。しかし，術後 ADL の低下を認めなかった症例と $\mathrm{ADL}$ が低下した症例を比較すると，低下のみられなか った症例か，平均 2.2 項目の異常であったのに対し，低 下症例は 1.7 項目と，むしろ少なめであり，術前の併存 疾患と ADL の低下には相関は認められなかった。

林ら (3)は, 高齢者手術では待機手術に比し緊急腹部 手術の直死率が非常に高いと述へているが，今回検討 した症例においても緊急手術 8 例中，急性虫垂炎 3 例 を除く 5 例は，いずれも重篤な合併症をおこし在院死 亡となった。いっぼう，待機手術においては術前併存 疾患や検查値異常を有している症例においても，縫合 不全から腹膜炎を併発した 1 例を除いては，術後の合 併症は比較的軽度であり，高齢者といえども適切な手 術適応の决定を行えは，耐術は十分可能であると思わ れな。しかし耐術し，退院可能であった症例において も術前に比し術後 ADL が低下することにより在院日 数が延長したり，家疾の介護負担が増加する例がみら れたため, 退院可能となった30例につき，術前後にお ける ADL，寝たきり度の変化を検討した。

山本ら ${ }^{14}$ は高龄者の胃癌症例について検討し, 術後 のQOL の重要性について述へているが，同時にその 客観的評価の困難さも指摘している. 著者らは今回誛 たきり度の判定に，介護保険制度において要介護度の 判定に使われる基本調査項目のなかの「障害老人の日 常生活自立度（寝たきり度）」の判定基準を採用した。
この判定基準は地域や施設などの現場において，保健 婦などが何らかの障害を有する高龄者の寝たきり度を 客観的かつ短時間に判定することを目的として作成さ れたものであり, 自立度の判定と併せて保健, 福祉サ 一ビスの供給量の基礎資料とするため, 個人の ADL に関する項目も設定されている ${ }^{8)}$. 判定の項目は「移 動」,「食事」,「排泄」,「入浴」,「着替」, 「整容」,「意 思疎通」であり，今回の ADL の判定はこれら 7 項目を 利用した。

術後の ADL, 寝たきり度の状況を. 評価する時期に 関しては，同じ疾患でっって，その回復に個人差が あったり，また合併症の有無によっても回復過程が異 なっていたり，回復後の家族の受け入れ状況もまちま ちであり，一定の期間を区切っての判定は困難であっ た。このため評価は合併症の治療を合め, 退院可能と 判断された時点でまた ADLが低下し寝たきり度が 上昇して自宅での介護体制が整わない症例に関しては 併設の介護療養型施設に転棟する時点で行った。

森田ら ${ }^{15}$ は高齢者大腸癌手術において排尿障害や排 便機能の低下は，ょり高度で回復遅延の傾向が強いこ とを指摘しているが, 著者らの検討でも直腸癌の術後, 1 例に排尿障害の増悪を認めた。衍前にも，時に失禁 を認め, 術後にその頻度の増加を認めたものだが，手 術時における直接の神経障害の可能性を考慮し，今回 排泄面における ADL の低下例には含めなかった。 ま た人工肛門を造設した症例においても，装具の交換な どの自己処置が可能な場合には低下とは判定しなかっ た。

高齢者手術の合併症は，術中出血量や手術時間に左 右されるといわれておりい16)17，また合併症を少なくす る麻酔法の検討も種々なされている ${ }^{1819}$ が今回術後に ADLの低下を認めた例と認めなかった例を比較して も，その手術時間，術中出血量，麻酔法には明らかな 差は認められなかった。しかし，術後合併症が認めら れた症例は，認められなかった症例に比へ，ADLの低 下を認める頻度が高い傾向をしめしていた，今回 ADL の変化を検討した30例の平均入院日数は61.3日であっ たが，合併症のみられた症例は76日，みられなかった 症例は57.5日であった。ささらに，合併症を認めた症例 のうち，ADLの低下がみられた症例は105.3日，みら れなかった症例は61.3日であり，ひとたび合併症をお こし，入院期間が延長すると，ADLの低下をひきおこ す可能性は高くなると思われた。しかし，合併症をお こさなかった21例中 3 例 $\left(14.3^{\circ}{ }_{0}\right)$ に执いてもADLの 
低下は認められており、このうちの 1 例は, 術前の「生 活自立」から「寝たきり」へと著明な低下がみられて いた．東山ら ${ }^{201}$ は高齢者の胃癌症例において，quality of life を考慮した合理的な手術の必要性を述へてている が, 高齢者手術では手術適応, 手術法, 麻酔法などを 工夫し合併症をおこさないようにすることは，もちろ ん重要であるが，術前の全身状態が良奵で，大きな合 併症がないような症例においても，ひとたび手術侵襲 が加わることにより ADLが著しく低下する可能性が あることを考虑にいれなければならないと思われた。 今回検討した ADL 低下例の退院後経過をおってみて も，1例が移動面でやや改善を認めたのみであり，い ちど ADL の低下をおこせば，老人介護の問題は本人 ばかりではなく家族にも大きな精神的，経済的負担を 強いる可能性があり．治療する側は耐術面ばかりにと らわ机な゙，術前，家族や本人に対し術後に拀こりうる $\mathrm{ADL}$ 低下の可能性や介護の必要性に関し十分なイン フォームドコンセントを与え，家族の介估体制を把握 し，不幸にして ADL の低下を認めた場合でも,ケース ワーカー, ケアマネージャーらとの連携を図り, 適切 な介護支援が提供出来るような体制を整えて手術に臨 むべきであると思われた。

\section{結 語}

1. 1992年4月より1999年 3 月までの高齢者消化器 外科手術症例を, 術前, 術後のADL, 寝たきり度の変 化を中心に模討した。

2。症例は男性17例，女性23例。良性疾患15例，悪 性疾患25例であった。

3. 術前検査值異常は90 ${ }_{0}^{\circ}$ の症例に認めたが，緊急 手術と悪性腫湯に対する姑息手術以外では重篤な合併 症は少なく，高齢者といえども比較的安全に手術可能 であった。

4. 退院可能であった30例においては, 術前に比し, 術後に移動，排泄を中心に2 $20 \%$ 症例て ADL の低下 がみられた，寝たきり度に扔いても「生活自立」から 「骎たきり」となった症例も2 例認め，高龄者手術に おいては耐術面にのみとらわれだ,ADL，の低下に対す る十分な情報提供と，きめ細かな介謢支援の提供が出 杉体制を整えて手術に臨むへきであると思われた。

なお，位淌文の要旨は第61回日本臨床外科学会総会（東 京）において発表した。

$$
\text { 文献 }
$$

1）石山 $\mathrm{i}$, 森岡恭彦, 渡辺厂之他：高龄者消化器 手術の適応限界。手術 $41: 37-42,1987$
2）武川 悟, 長演 徵, 吕木裕一他：超高齢者大腸 癌切除症例の検討. 日臨外医会誌 $57: 2641-$ 2645,1996

3）待木雄一, 太田博俊, 晆倉 蕉他：高龄者大腸癌 の臨床的検討. 日消外会誌 $24: 81-88,1991$

4）大谷吉秀，戸倉康之，山滕和夫他：高龄者（80歳 以上）胃癌切除例の検討一遠隔成績からみた外科 治療上の問題点一. 日臨外医会誌 $55: 547--554$, 1994

5）羽生 尔, 鴻野雅司, 谷 雅也他：高龄者胃癌の 適応判断. 日消外会榺 $20: 2427-2430,1987$

6）永田松夫，落合武徳，鈴木孝雄他：教室における 高齢者罗癌（80歳以上）の治療と問題点. 日臨外 医会誌 54：1173-1179，1993

7）川原田嘉文, 岩崎 誠, 岩田 真: 高齢者手術に おけろ術前評価とその対策. 消外 $14: 29-36$, 1991

8）厚生省高龄者ケアサービス体制整備检討委員会： 介護支援専門員標準テキスト，第 2 巻，補訂版， 財団法人長寿社会開発センター, 東京, 1998, p222 $-225$

9）石神純也，山田一隆，朝沼 榎他：高齢者大腸癌 の外科治療について. 日消外会誌 $27 ： 1961-$ 1967, 1994

10）校本邦男, 岡島邦雄, 山田真一他：满80歳以上高 踰者胃癌手術例の検討。日臨外医会誌 $50: 147 i$ $-1482,1989$

11）内田信之, 小板橋宏, 長町幸雄：高齢者（80歳以 上）の肖癌，大腸癌の椎沽 $\cdots$ とくに術後合併症を 中心に一，日臨外医会誌 $55 ： 1947-1952 ， 1994$

12）長見晴彦, 田村勝洋, 中瀬 明: 高齢者胃癌手術 症例の臨床的検討一特に70歳手術症例と80歳手術 症例の比較を中心として一，日臨外医会誌 52 ： $2559-2565,1991$

13）林四郎，市川英幸：老人に対する手術適応の判 断. 治療 $68: 479 \quad 48.5,1986$

14）山本䉆志, 河野博光, 船越真人他：高龄者 $(80$ 歳 以上）望癌症例の予後に関する検討一手術例と非 手術例の比较模討一。 日臨外会誌 $59: 1984-$ 1988, 1998

15）森田隆幸，櫺川 正，今 充他：高路者大腸癌 症例の検討，日消外会誌 $20: 2431-2434,1987$

16）紧本邦男, 岡島邦雄, 富士原彰他：高粭者胃癌手

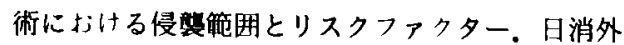


会誌 $19: 2100-2103,1986$

17）藤井一郎, 広瀬周平, 高橋健治：80歳以上の高齢 者の消化器手術における術後合併症。日消外会誌 $19: 729-733,1986$

18）槙島敏治, 遠藤 健, 喜島健雄他：80歳以上の高 齢者の消化器手術における術後合併症。日臨外医 会誌 $51: 239 \cdots 243,1990$
19）福井 聖, 竹山栄子：80歳以上の開腹手術の心,

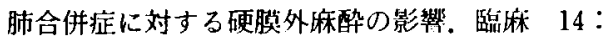
$1023-11024,1990$

20）東山孝一, 梨本 篤, 佐尔尋英他：80歳以上の 高跲者胃癌におりる外科治療上の問題点. 日消外 会誌 $24: 771-778,1991$

\title{
CLINICAL STUDY ON GASTROINTESTINAL SURGERIES FOR PATIENTS OVER THE AGE OF 80-EVALUATION OF PRE AND POSTOPERATIVE CARE-
}

\author{
Osamu TAKAHASHI, Tsukasa SHIMIODA. Shunhan $\mathrm{KOH}^{*}$ and Sachio ENDO \\ Department of Surgery. Heiwa Hospital \\ -First Department of Surgery, School of Medicine, Chiba University
}

Forty cases of gastrointestinal surgery in patients over the age of 80 who were treated at our hospital between April 1992 and March 1999 were studied in terms of changes in pre and postoperative activity of daily life (ADL) and the degree to which the patients were bedridden. Preoperative abnormalities in laboratory data and underlying disorders were confirmed in $900^{\circ}$ of the subjects. Except for cases of emergency operation and those of palliative surgery for malignancy, none of the cases undergoing elective surgery experienced severe complications and all cases were able to tolerate the surgeries. However, when changes in ADL were reviewed in 30 patients who had been discharged, some deterioration in movement and excretion were observed in six patients $\left(20{ }^{\circ}{ }_{0}\right)$. Two patients experienced a significant deterioration, from 'independent' to 'bedridden'.

Surgical intervention should be minimized in elderly patients, and the possibility of a postoperative deterioration in ADL should be considered in addition to the patient's ability to tolerate the operation. Srstems offering postoperative support and care should also be established. 